\title{
Die Nuwe Testament en mitologie: Die probleem van die ontmitologisering van die Nuwe-Testamentiese verkondiging. Bultmann se 1941-opstel weer bekyk
}

\author{
Author: \\ Gert J. Malan ${ }^{1}$ \\ Affiliation: \\ ${ }^{1}$ Research Associate, \\ Reformed Theological \\ College, Faculty of Theology, \\ University of Pretoria, \\ South Africa \\ Correspondence to: \\ Gert Malan \\ Email: \\ gertmalan@telkomsa.net \\ Postal address: \\ PO Box 1775, Mossel Bay \\ 6500 , South Africa \\ Dates: \\ Received: 05 June 2014 \\ Accepted: 20 Oct. 2014 \\ Published: 29 May 2015 \\ How to cite this article: \\ Malan, G.J., 2015, 'Die Nuwe \\ Testament en mitologie: \\ Die probleem van die \\ ontmitologisering van \\ die Nuwe-Testamentiese \\ verkondiging. Bultmann se \\ 1941-opstel weer bekyk', \\ HTS Teologiese Studies/ \\ Theological Studies 71(3), \\ Art. \#2757, 8 pages. http:// \\ dx.doi.org/10.4102/hts. \\ v71i3. 2757

\section{Copyright:} \\ (C) 2015. The Authors. \\ Licensee: AOSIS \\ OpenJournals. This work is \\ licensed under the Creative \\ Commons Attribution \\ License.
}

Read online:

Scan this $Q R$ code with your smart phone or mobile device to read online.
In the Afrikaans-speaking South African theological context, there was little positive regard for Bultmann's work, especially for his demythologising program. More than seventy years have passed since Bultmann's 1941 essay on demythologising started a lively debate. For most, Bultmann and his legacy have receded into the past. With the 130th commemoration of Bultmann's birthday this year, it seems appropriate to revisit his 1941 essay on demythologising. The purpose of this paper is to listen again to the voice of Bultmann, unhindered by the interpretations of his work by others. This is possible, as the dust has long settled after the demythologisation debate. This exercise may reveal that Bultmann's work is still relevant in our new theological context.

\section{Inleiding}

Rudolf Bultmann was die mees invloedryke Bybelwetenskaplike van die 20ste eeu en het bakens verskuif wat blywende resultate gelewer het (Van Aarde 2011:1). Hoewel Bultmann se werk in geheel eintlik afgestem is op die interpretasie van die mitiese spreke in die Nuwe Testament, was dit sy 1941-opstel wat die ontmitologiseringsdebat in beweging gebring het (Dunn 1977:295). Schubert Ogden (1985:vii) beskryf hierdie opstel van Bultmann oor ontmitologisering as die mees opspraakwekkende en kontroversiële teologiese geskrif van die twintigste eeu. Dit is die klassieke formulering van Bultmann se standpunt oor die saak en as sodanig is dit onvergelyklik in die korpus van sy werk. Buiten vir 'n handjievol, was daar min Suid-Afrikaanse teoloë wat positiewe waardering vir Bultmann se ontmitologiseringsprogram gehad het (vgl. Pelser 1987:162). Meer as sewentig jaar het verloop sedert Bultmann se 1941-opstel die ontmitologiseringsdebat ontketen het (Dunn 1977:295). Intussen het die debat afgesluit en die stof daaroor het gaan lê. Met die 130ste herdenking van Bultmann se geboortedag vanjaar is dit gepas om weer sy eerste opstel oor ontmitologisering af te stof. Die bedoeling met die artikel is om weer na Bultmann se stem te luister, ongehinderd deur die stemme van sy kritici, en hulle daarna aan die woord te stel. Die titel van hierdie artikel bevat daarom die Afrikaanse weergawe van die Duitse titel van sy 1941 opstel.

\section{Bultmann se motivering vir ontmitologisering}

Die grondmotief vir ontmitologisering was om die Nuwe-Testamentiese verkondiging vir moderne mense te ontsluit. Vir Bultmann was dit ondenkbaar dat moderne mense, met 'n werklikheidsverstaan gevorm deur wetenskap en tegnologie die mitologies verwoorde verkondiging van die Nuwe Testament sal verstaan en aanvaar. Dit verg 'n prysgawe van die intellek. Die Nuwe-Testamentiese verkondiging moet verstaanbaar interpreteer word sodat dit hedendaagse mense eksistensieel sal aanspreek (Bultmann [1941] 1967:16-21).

\section{Mitiese wêreldbeeld}

Waarom sou die Nuwe-Testamentiese verkondiging dan vir moderne mense onverstaanbaar wees? Eerstens vorm die drieverdieping- mitiese wêreldbeeld die denkraamwerk van die Nuwe Testament (Bultmann [1941] 1967:15-16). Die aarde vorm die middelste verdieping, met die hel daaronder en die hemel daarbo. Die aarde as leefwêreld van mense is oop vir invloede van bo of onder: God en sy engele kan ingryp in mense se gedagtes en handelinge, maar net so Satan en sy demone. Hierdie tydvak in die mag van Satan, sonde en dood, stuur 'n spoedige einde tegemoet, wat katastrofaal sal eindig. Dan volg die opstanding van die dooies en die eindoordeel.

Hierdie voormoderne werklikheidsverstaan verklaar gebeure as bo-natuurlike ingrype. Moderne wetenskaplik-georiënteerde mense redeneer nie meer so nie. Siekes gaan dokter toe en beskou nie siekte as God se straf of Satanswerk nie. Biologiese verklarings en behandeling van siekte maak die teodiseevraag en die mitiese denke oorbodig. 


\section{Die heilsgebeure in mitologiese taal weergegee}

Tweedens, en van groter belang as die mitologiese denkraamwerk, is die probleem dat die heilsgebeure boonop in mitiese taal beskryf word. Dit is vir hedendaagse mense onverstaanbaar (Bultmann [1941] 1967:15-16).

So verkondig die Nuwe Testament:

- die laaste dae het aangebreek

- in die volheid van die tyd het God sy Seun gestuur

- die Seun, pre-eksistente God, verskyn op aarde as 'n mens

- met sy kruisdood word hy plaasvervangend tot sondaar gemaak

- so bring hy versoening vir mense se sonde

- sy opstanding is die begin van die kosmiese katastrofe waardeur die dood oorwin word, wat deur Adam gekom het

- die demoniese magte het hulle krag verloor

- die opgestane Heer word verhoog tot die regterhand van God

- hy word Heer en Koning gemaak

- hy sal terugkeer op die wolke om finaal die oordeel en verlossing te voltrek

- met sy koms sal die opstanding van die dooies plaasvind en die eindoordeel

- sonde, dood en alle lyding sal ophou

- die gemeenskap van gelowiges het aan Christus deel deur die doop en nagmaal, en sal aan die verlossing deel kry mits hulle volhard

- gelowiges ontvang nou reeds die eerste vrugte hiervan, naamlik die Heilige Gees as waarborg dat hulle kinders van God is en sal opstaan uit die dood.

Hierdie mitiese spreekwyse is die taal van die Joodse apokaliptiek en die Gnostiese verlossingsmite. Beteken geloof om hierdie mitiese spreekwyse en verwysingsraamwerk te aanvaar? Indien nie, is die wesensvraag of die Nuwe Testament ' $n$ waarheid bevat wat los van hierdie wêreldbeeld as verwysingsraamwerk verkondig kan word. Indien wel, moet teologie die Christusverkondiging ontmitologiseer (Bultmann [1941] 1967:16).

\section{Wat mites tot uitdrukking bring}

Mites verklaar die kragte wat op mense inwerk en hulle lewens begrens, as bonatuurlik. 'n Mitiese kosmologie of wêreldbeskouing ontwikkel as verklarende verwysingsraamwerk waardeur mense 'n greep op die bonatuurlike kry. Dit gebeur omdat mites oor die bonatuurlike in menslike of wêreldse terme praat. Die bonatuurlike word geobjektiveer tot die ondermaanse, en daarmee tot iets beheerbaars (vgl. Bultmann [1941] 1967:23).

Mites verwoord die begrensheid van menslike eksistensie, maar die objektiverende voorstellingswyse versluier en belemmer dit. Mites demonstreer dat die bekende, verbygaande wêreld sy oorsprong en betekenis vind in die bonatuurlike. Menslike bestaan word beheer en bedreig deur bonatuurlike magte wat dit begrond en begrens. Mense is nie in beheer van hulle lewens en lotgevalle nie, maar is uitgelewer aan, of afhanklik van die bonatuurlike magte wat die werklikheid beheer (Bultmann [1941] 1967:22-23).

Mites wil nie 'n objektiewe prentjie van die werklikheid daarstel nie, maar aandui hoe mense hulleself verstaan binne hulle leefwêreld. Mites behoort daarom nie in kosmologiese terme verklaar te word nie, maar in antropologiese terme of beter nog, in eksistensiale terme. Taal is ontoereikend vir spreke oor die bonatuurlike. Analogiese taal is al uitweg uit die impasse. So kom die bonatuurlike tot binne mense se bekende leefwêreld, emosies, motiewe en moontlikhede. Eksistensiale interpretasie is nodig om mites se bedoeling te ontbloot, naamlik om menslike eksistensie tot uitdrukking te bring. Die objektiverende spreekwyse van mites versluier hierdie bedoeling en moet ontmitologiseer word ten einde te verstaan hoe menslike eksistensie daarmee belig word (Bultmann [1941] 1967:22-23). Voorbeelde hiervan is die ontmitologisering van die heilsgebeure.

\section{Ontmitologisering}

\section{Die bedoeling daarmee}

Ontmitologisering beteken nie vir Bultmann die wegsny van die mitiese, soos die benaming suggereer nie (vgl. Malan 2000:1108). Die mitologie moet na sy ware intensie interpreteer word, naamlik as uitdrukking van menslike eksistensie. Daarom is ontmitologisering eksistensiale interpretasie. Bultmann ([1941] 1967:26-27) steun op Hans Jonas se 1921 boek Gnosis und Spätantiker Geist, wat die Gnostiese verkondiging in eksistensiale terme interpreteer het. In die voorwoord skryf hy dat Jonas se metode van ontmitologisering briljant daarin slaag om die ware betekenis van die gnostiese spreekwyse bloot te lê deur eksistensiale analise en dat die metode vrugbaar aangewend sal kan word vir die verstaan van die Nuwe Testament (Robinson 1964:3435). Ontmitologisering het dus nie met die wegsny of afskil van die mitologie te doen nie, maar met die vertaling van die dualistiese en apokaliptiese mitiese spreekwyse in ekstensiale terme ten einde die selfverstaan wat daarin vervat word, tot spreke te bring.

\section{Ontmitologisering van die Christelike synsverstaan (Seinsverständnis)}

Bied die Nuwe-Testamentiese dokumente wel aan ons 'n selfverstaan wat ons eksistensie eg bevraagteken en 'n eksistensiële beslissing verg? Bultmann ([1941] 1967:27) meen wel so en interpreteer fasette van die mities verwoorde Nuwe-Testamentiese verkondiging kortliks in eksistensiale terme. Hy onderskei tussen menslike bestaan sonder geloof en menslike bestaan vanuit geloof.

\section{Menslike bestaan sonder geloof}

Hierdie wêreld (kosmos) is deur God geskep, maar is saam met mense uitgelewer en verval onder Satan se mag. Mense bly self verantwoordelik vir hulle sonde en sal aan 
God rekenskap moet gee. God beperk Satan se mag op vreemdsoortige manier. Adam, die eerste sondaar, het die dood gebring, maar die dood is ook die loon van elke mens se eie sonde. Adam was die eerste mens of vlees (sarks). 'Vlees' verwys in eksistensiële terme na die menslike leefwêreld van die sigbare, beskikbare, beheerbare en meetbare; kortom: die verganklike. Sedert Adam swig alle mense voor die versoeking om vanuit hierdie sigbare, verganklike werklikheid te leef eerder as vanuit die onsigbare en onbeheerbare. 'Vlees' verteenwoordig sodoende 'n mag wat beheer neem van mense, omdat mense dit tot basis van hulle bestaan maak, ongeag of hulle verantwoordelik of onverantwoordelik sou leef. Selfs hulle verdienstelikheid is gebonde aan die verganklike, en is daarom van geen waarde nie, net soos enigiets anders wat die mens verwerf en waarop hulle vertrou.

Eie aan die verganklikheid is die menslike kommer of besorgdheid (merimnān) om sekuriteit daar te stel. Volgens elkeen se moontlikhede en suksesse hiermee kom daar ' $n$ bewussyn van sekuriteit, waarop mense uiteindelik roem (kauchasthai). Hierdie gesindheid is eintlik ondenkbaar, in die lig van die verganklikheid van alle aardse sekuriteite. Maar juis op hierdie manier verloor mense hulle outentieke eksistensie en word prooi van die verganklike dinge waarop hulle vertrou het en gemeen het om te beheer. Nou beheer dit húlle lewens en is hulle slawe in diens daarvan. Die gevolg: hulle word soos die wêreldse dinge waarop hulle vertrou, uitgelewer aan verganklikheid en dood. Wie leef in vertroue op wat beheerbaar en verbygaande is, maak hulleself afhanklik daarvan. Alle mense doen dit, en kom daarom met mekaar in konflik. Elkeen probeer homself teen ander beveilig. Hieruit ontstaan naywer, woede, jaloesie en stryd, maar ook verdrae en ooreenkomste vir samewerking en algemeen geldende waarde-oordele en standaarde. Hierdeur skep mense 'n verwysingsraamwerk waaraan ons onsself voortdurend meet en die waardestelsel herbevestig. Só versterk mense die angsvolle ervaring wat ons vir mekaar geheim hou, naamlik hoedat ons ervaar dat alles, ook ons eie lewe, besig is om van ons af weg te gly (Bultmann [1941] 1967:27-29).

\section{Menslike bestaan vanuit geloof}

Hierteenoor, in eksistensiale terme vertaal, verkondig die Nuwe Testament lewe in vertroue op en vanuit die Onsigbare. Dit beteken prysgawe van alle selfgemaakte sekuriteite en lewe vanuit geloof, menende vertroue dat die Onsigbare, Onbekende en Onbeheerbare mense ontmoet as liefde wat vir hulle lewe en daarmee 'n toekoms skenk (Bultmann [1941] 1967:29).

God se genade is sondevergewend. Sonde is in eksistensiale terme daardie gesindheid van mense om hulle lewens te probeer verseker en beveilig deur sekuriteite daar te stel, daaraan vas te klou en uiteindelik daarvoor te leef. Juis omdat hierdie gesindheid mense afsluit van die Onsigbare en die toekoms waarin God Homself aan ons gee, is dit sonde (Bultmann [1941] 1967:29). Eksistensiaal beskou, bevry God se vergifnis mense dus van hierdie afsluiting van God en verknegting aan die verganklike, sodat hulle vry kan word vir God se toekoms vir hulle. Geloof (wat die vergifnis aanvaar) is om oop te wees vir God se toekoms. Geloof is daarom ook gehoorsaamheid, naamlik die wegdraai van die self, bedoelende prysgawe van die self en sy verknogtheid aan sekuriteite. Geloof is die afsweer van enige pogings om self vir God aanvaarbaar te wees of om uit onsself ware lewe daar te stel. Geloof is radikale onderwerping aan God as die Een wat dooies opwek en dinge daarstel wat nie voorheen bestaan het nie. Geloof verwag alles van God en niks van onsself nie. Daarmee word mense bevry van gewaande aardse sekuriteite en die valse vryheid wat dit beloof (Bultmann [1941] 1967:29).

Hierdie vryheid is nie asketisme nie. Gelowiges onttrek nie aan die wêreld nie. Hulle neem deel aan die dinge in hulle leefwêreld, maar asof op 'n afstand, asof nie. Gelowiges is nie meer slawe van aardse dinge nie. Hierdie wêreld is vir die gelowiges gekruisig en hulle vir die wêreld. Alles van die wêreld het vir hulle na die agtergrond verskuif as dinge wat geensins betekenis in sigself het nie. Bultmann ([1941] 1967:19) gebruik die term Indifferenz om gelowiges se gesindheid jeens wêreldse dinge mee uit te druk. Die krag van gelowiges se nuwe lewe kom tot uitdrukking in hulle swakheid, lyding en dood. Eers wanneer hulle bewus word van hulle eie nietigheid, dat hulle op sigself niks is nie, kan hulle van Godsweë alles hê en wees (Bultmann [1941] 1967:19).

Om só te leef is om eskatologies te leef, om 'n nuwe mens te wees. Hiermee is die Joodse apokaliptiese eskatologie ontmitologiseer, deurdat die dag van oordeel alreeds aangebreek het. Die Johannes-evangelie maak die radikale gevolgtrekking dat die oordeel oor die wêreld nie 'n toekomstige kosmiese gebeure sal wees nie, maar reeds met Jesus se oproep tot geloof gekom het. So elimineer die Johannes-evangelie in geheel die apokaliptiese eskatologie. Gelowiges het reeds die lewe, en het uit die dood na die lewe oorgegaan. Uiterlik het niks verander in hulle verhouding met die wêreld nie, maar vir hulle is die wêreld (as verteenwoordigend van die verganklike, nie in terme van etiese verantwoordelikheid nie) nie meer van belang nie (Bultmann [1941] 1967:20). Ook die Gnostiese eskatologie word so oorkom. Gelowiges kry nie 'n nuwe natuur nie, hulle pre-eksistente natuur word nie bevry nie, en hulle hemelwaartse sielereis word nie gewaarborg nie. Wat hulle in geloof het, is nie 'n gegewendheid, 'n gewaarborgde toestand, sodat libertinisme kan volg of angsvallige asketisme dit moet beskerm nie. Nee, naas die indikatief van geloof staan die imperatief. Geloof is nie 'n eenmalige, eens en vir altyd beslissing nie, maar moet in elke nuwe konkrete situasie bevestig word deur die geloofsbeslissing opnuut te neem. Die vryheid van geloof is die vryheid om telkens weer die geloofsbeslissing te maak (Bultmann [1941] 1967:20).

\section{Ontmitologisering van die Heilsgebeure Christelike verstaan van lewe sonder Christus}

Geloof beteken in die Nuwe Testament ook geloof in Christus. Die Nuwe Testament verkondig dat geloof bekend gemaak 
is, gekom het. Geloof het eers moontlik geword weens die Christusgebeure. Geloof as gehoorsame oorgawe aan God en innerlike vryheid van die wêreld is alleen moontlik deur geloof in Christus (Bultmann [1941] 1967:31).

Is hierdie aanspraak 'n mitologiese res wat ontmitologiseer moet word? Kan die Christelike synsverstaan realiseer sonder Christus? Filosowe soos Graaf York van Wartemburg, Karl Jaspers en Martin Heidegger se werk suggereer dit. Bultmann oordeel dat wat die filosofie op sy eie oor menslike eksistensie waarneem, ook in die Nuwe Testament tot uitdrukking kom (Bultmann [1941] 1967:32-33). Heidegger se eksistensiale analise van menslike eksistensie bied 'n uitnemende profane voorstelling van die Nuwe-Testamentiese siening daarvan: angsvolle eksistensie moet voortdurend kies tussen sigself verloor aan die voorhande wêreld of outentieke eksistensie, deur alle sekuriteite prys te gee en vry te wees vir die toekoms.

Die vraag is nie of die aard van menslike eksistensie sonder die Nuwe Testament verstaan kan word nie, maar of outentieke eksistensie sal realiseer bloot omdat dit aan mense verduidelik word en hulle daartoe opgeroep word, soos die filosofie meen (Bultmann [1941] 1967:33-34). Op hierdie kritieke punt antwoord die Nuwe Testament negatief: outentieke eksistensie kan alleen realiseer deur die bevrydende daad van God, naamlik die verlossingsgebeure wat Christus verwesenlik het. Sonder hierdie verlossingsdaad van God is die mens se situasie desperaat (verzweifeld) (Bultmann [1941] 1967:35).

Die Nuwe Testament praat met gelowiges, dus met mense wat die beslissing gemaak het om God se verlossingsdaad in hulle eksistensie te laat plaasvind (Bultmann [1941] 1967:36). Mense herken buite die Nuwe Testament om hulle nie-outentieke eksistensie (Vervallenheit), omdat kennis van outentieke bestaan deel is van menslike eksistensie. Die belangrike punt is dat outentisiteit (Eigentlichkeit) nie 'n natuurlike, menslike eienskap is waaroor ons beskik sodat ons dit kan verwesenlik, soos die filosofie meen nie. Die Nuwe Testament leer dat mense juis hulle outentisiteit verloor het en dat hulle kennis van outentisiteit vervals word deur die idee dat mense oor outentisiteit kan beskik. Vervallenheid dui aan dat alle pogings om outentiek te eksisteer onsuksesvol sal wees omdat dit steeds die pogings van vervallenes is wat nie self aan hulle vervallenheid kan ontkom nie (Bultmann [1941] 1967:37). Die Nuwe Testament noem hierdie toedrag van sake sonde, en die aanspraak om self (eigenmächtig) outentiek te kan leef is die wesenlike aard van sonde (Bultmann [1941] 1967:38). Hierdie selfvertroue (Eigenmächtigkeit) is ondankbaarheid jeens God en sluit mense af van die moontlikheid om outentiek te eksisteer, naamlik deur onderwerping aan God. Outentieke eksistensie is nie 'n taak wat die mens kan bemeester nie, maar 'n geskenk van God wat mense bevry om outentiek te kan eksisteer. Omdat hierdie selfvertroue so wesenlik deel uitmaak van menswees, beteken die verlossingsdaad van God dat ons in wese van onsself bevry word (Bultmann [1941] 1967:38). Mense is so vervalle dat niemand eens hulleself aan God kan onderwerp nie, al probeer hulle ook hoe hard. Tot outentieke bestaan kan 'n mens alleen maar bevry word. Presies dít verkondig die Nuwe Testament en die Christusgebeure: waar ons nie self kon optree nie, het God vir ons opgetree (Bultmann [1941] 1967:38-39).

Vergifnis van sonde moet nie juridies verstaan word as die blote afskryf van skuld of straf, sodat menslike bestaan onveranderd kan bly nie. Vergifnis is eerder die bevryding van daardie mag wat ons tot hiertoe gevange gehou het. Vergifnis is daarom bevryding tot gehoorsaamheid. Eskatologiese (outentieke) eksistensie word moontlik omdat God opgetree en mense deur die Christusgebeure van die houvas van hierdie wêreld bevry het. Dit is die bekendmaking van God se liefde. Alleen geloof in hierdie liefde van God maak mense vry van hulleself en oop vir God se toekoms. Christelike geloof is daarom altyd geloof in Christus as die bekendmaking van God se liefde (Bultmann [1941] 1967:39). Kom daar hiermee 'n beperking op die ontmitologisering van die Nuwe-Testamentiese verkondiging? Het ons hier voor 'n mite te staan gekom, of voor 'n gebeurtenis wat mitologiese karakter toon? Die vraag is dus of die volgende uitspraak 'n mitologiese aanspraak is: die verandering tot mense wat bevry is van hulleself om outentiek te lewe, is slegs moontlik as 'n daad van God en geloof is alleen geloof in die liefde van God wat bekend gemaak is in die Christusgebeure.

\section{Die Christusgebeure}

Die vraag aan die orde is derhalwe of die bekendmaking van God se liefde deur die Christusgebeure 'n mitiese gebeure is.

Die probleem rondom ontmitologisering van die Christusgebeure: Bultmann sê onomwonde die Nuwe Testament stel die Christusgebeure as 'n mitiese gebeure voor. Die eintlike vraag is of dit so voorgestel hoef te word, en of die Nuwe Testament nie reeds self vir ons van ontmitologiserende interpretasie voorsien nie (Bultmann [1941] 1967:40-41).

Die vervlegtheid van die mitiese voorstellings oor die pre-eksistente, maagdelik-gebore Seun van God met die historiese Jesus van Nasaret laat Bultmann vra of die mitiese voorstellingswyse nie bedoel om die betekenis van die historiese Jesus weer te gee nie: die Verlosser en sy oorsprong is nie te verstaan vanuit die konteks van hierdie wêreld nie, maar vanuit die ewigheid (Bultmann [1941] 1967:41). Bultmann sluit af deur die kruis en opstanding ontmitologiserend te interpreteer.

Die kruis: Moet die betekenis van Christus se kruisdood slegs as mitiese gebeure verstaan word, of as historiese gebeure, wat tegelyk die verlossingsgebeure is? Die Nuwe Testament teken beslis die kruisgebeure as mities: die gekruisigde is die pre-eksistente Seun van God wat mens word en daarom sondeloos is. Hy is die offer deur wie se bloed ons sonde versoen word. Hy dra plaasvervangend die wêreld se sonde deur die dood as straf vir sonde op Hom te neem. So bevry 
Hy ons daarvan (Bultmann [1941] 1967:41-42). Hierdie mitiese voorstelling vermeng gedagtes oor die offerkultus met ' $n$ juridiese satisfaksieteorie. Dit is daarom nie meer vandag aanvaarbaar is nie. Dit sê ook nie alles wat oor die kruisgebeure gesê behoort te word nie. Al wat dit aandui, is dat vergifnis die straf vir sonde wegneem. Meer behoort gesê te word, naamlik dat die kruisgebeure gelowiges bevry van die mag van sonde wat hulle domineer (Bultmann [1941] 1967:42). Sodoende word die historiese gebeure tot kosmiese gebeure verhef en die kruisgebeure word die oordeel oor die wêreld. Deur toe te laat dat Jesus gekruisig word, het God die kruis daargestel as kruis vir ons. Geloof in die kruis van Christus beteken om dit as jou kruis te aanvaar en saam met Christus gekruisig te word. Dit is dan nie 'n mitiese gebeure buite ons, of 'n objektief waarneembare gebeure wat God tot ons krediet reken nie. Die beslissende betekenis van die kruisgebeure is dat dit die geskiedenis transformeer omdat dit die eskatologiese gebeure is wat verby die grense van tyd reik. Vir gelowiges is die betekenis van die kruisgebeure 'n konstante werklikheid (Bultmann [1941] 1967:42). Die sakramente demonstreer dit: die doop beteken om saam met Christus gekruisig te word en te sterf. Nagmaalgangers kry deel aan Christus se liggaam en bloed, dus aan sy sterwe. Ook in die gewone lewe is die kruis van Christus aanwesig deur die afsterf van eiebelang en aanvaarding van lyding. Sodoende bly die kruisgebeure 'n konstante werklikheid en is dit nie beperk tot iets van die verlede nie. Bultmann se gevolgtrekking is dat die kruisgebeure as verlossingsgebeure nie mitiese gebeure is nie, maar historiese gebeure, wat sy oorsprong in die historiese kruisiging van Jesus van Nasaret het. Die mitiese inkleding wil niks anders wees nie as 'n aanduiding van die belangrikheid van die historiese gebeure. Dit is in terme van hierdie betekenis van die kruisgebeure dat die verkondiging daarvan voortdurend toehoorders afvra of hulle bereid is om hierdie betekenis toe te eien en saam met Christus gekruisig te word (Bultmann [1941] 1967:43).

Is dit van deurslaggewende belang dat die kruis juis die kruis van Christus is? Vir die eerste gelowiges wel, want hulle het Jesus persoonlik geken. Met ons is dit anders. Dit is nie gebeure binne ons eie lewens nie. Ons ken dit alleen danksy die historiese berigte daaroor. Die Nuwe Testament dui nie die betekenis van Jesus se kruis vanuit sy historiese lewe aan nie, sodat historiese navorsing dit kan reproduseer nie. Die Gekruisigde word verkondig as die Opgestane. Kruis en opstanding vorm 'n eenheid (Bultmann [1941] 1967:43).

Die opstanding: Is die opstanding van Jesus 'n suiwer mitiese gebeure? Dit is nie 'n historiese gebeure (historisches Ereignis) nie. Die betekenis daarvan kan nie histories vasgestel word nie. Daarom kan die opstanding nie anders beskou kan word as uitdrukking van die betekenis van die kruisgebeure nie. Dit sê tog dat die kruisgebeure nie die dood van 'n gewone sterfling was nie, maar God se bevrydende oordeel oor die wêreld, wat ook die dood van sy krag beroof het. As kosmiese gebeure vorm die kruis en opstanding 'n eenheid, waardeur die moontlikheid van ware lewe geopen word. Die opstanding is egter nie te beskou as verifiërende mirakel (ein beglaubigendes Mirakel) om twyfelaars te oortuig dat die kruisgebeure werklik kosmies-eskatologiese betekenis het nie (Bultmann [1941] 1967:44). Die Nuwe Testament praat baie keer wel só oor die opstanding, maar dan in die meeste gevalle is dit latere formulerings. Die opstanding kan geensins as verifiërende mirakel dien nie. Nie net kan die opstanding nie as objektiewe feit bewys word nie, maar 'n mitiese gebeure, naamlik dat 'n dooie lewendig word, is op sigself ongeloofwaardig (unglaubhaft). Die opstanding is dus iets wat self geglo moet word. Die opstanding is objek van geloof, omdat dit veel meer sê as dat 'n dooie lewendig geword het. Dit is objek van geloof omdat dit'n eskatologiese gebeure is. Juis hierom kan dit nie 'n verifiërende mirakel wees nie. Geen mirakel kan getuig oor die eskatologiese feit dat die dood se mag verslaan is nie. Mens kan ook nie een saak wat geglo moet word (die eskatologiese betekenis van die kruis), met 'n ander saak wat ook geglo moet word (die opstanding van Jesus), bewys nie (Bultmann [1941] 1967:45).

Regdeur die Nuwe Testament word die opstanding geteken as eksatologiese gebeure waardeur Jesus die dood vernietig het en ware en ewige lewe aan die lig gebring het. Deur die doop kry gelowiges deel aan beide Jesus se dood en sy opstanding. Dit moet konkreet in hulle lewens bewys word deur teen die sonde te stry. Die opstanding is dus geen mitiese gebeure wat die betekenis van die kruis geloofwaardig maak nie. Die opstanding moet geglo word, net soos wat die betekenis van die kruis geglo moet word. Die opstandingsgeloof is niks anders nie as die geloof in die kruis as heilsgebeure, aan die kruis as die kruis van Christus nie. 'n Mens glo nie éérs aan Christus en daarná aan sy kruisdood nie. Om in Christus te glo is om in die kruis as die kruis van Christus te glo. Dit is nie omdat dit die kruis van Christus is dat dit heilsgebeure is nie. Omdat dit heilsgebeure is, is dit die kruis van Christus. Daarsonder is dit net die tragiese dood van 'n edele mens (Bultmann [1941] 1967:46).

Hoe word dit moontlik om die kruis as kruis van Christus te beskou, en daarmee as heilsgebeure en eskatologiese gebeure? Omdat dit so verkondig word, naamlik saam met die opstanding. Christus, die gekruisigde en verrese Heer, ontmoet ons in die verkondiging en nêrens anders nie. Ware Paasgeloof is om hierdie verkondiging te aanvaar (Bultmann [1941] 1967:46).

Dit sou ' $n$ fout wees om terugwaarts agter die verkondiging in te vra na die historiese oorspronge daarvan om dit sodoende te regverdig. Ons kan geloof nie deur historiese ondersoek regverdig nie. Die verkondiging ontmoet ons as God se woord; daarom vra ons nie dat dit gelegitimeer word nie. Dit bevraagteken óns juis, naamlik of ons bereid is om dit te glo. Die verkondiging vra ons om die kruis en opstanding as eskatologiese gebeure te glo, sodat nuwe moontlikhede vir ons selfverstaan daardeur geopen kan word. Hierdie soort geloof is ware Paasgeloof (Bultmann [1941] 1967:46).

Histories kan die Paasgebeure nie vasgestel word nie, alleen maar die Paasgeloof van die dissipels. Die Christelike 
Paasgeloof is egter nie geïnteresseerd in die historiese vraag daaroor nie. Vir gelowiges is die historiese ontstaan van die Paasgeloof van die dissipels die selfbekendmaking (Selbstbekundung) van die Opgestane Heer, die daad van God waarin die heilsbetekenis van die kruis voltrek word (Bultmann [1941] 1967:47). Die geloof van die dissipels word ook nie weer ' $n$ bewysbare feit op grond waarvan ons kan glo nie. Nee, die Paasgeloof self hoort tot die eskatologiese gebeure, wat die objek van geloof is. Daarmee word die verkondiging, wat sy oorsprong in die Paasgebeure het, self tot eskatologiese heilsgebeure. Bultmann kwalifiseer die verkondiging as dat dit mense vra om hulleself as Christus se mede-gekruisigdes en mede-verresenes te verstaan. In die geklank van die verkondiging word die kruis en opstanding tot hede gemaak en die eskatologiese oomblik breek aan. Dit is alleen in hierdie verkondiging dat ons die Opgestane Heer ontmoet (Bultmann [1941] 1967:47). Net soos die woord en die apostel wat dit verkondig, tot die eskatologiese gebeure hoort, so ook die kerk waar dit verkondig word aan gelowiges as versameling heiliges (mense wat die oorgang tot eskatologiese eksistensie gemaak het). Kerk (ekklesia) is ' $n$ eskatologiese begrip. 'Liggaam van Christus' druk die kosmiese aard daarvan uit: dit is nie ' $n$ historiese fenomeen in die sin van die wêreldgeskiedenis nie, maar in die sin dat dit in die geskiedenis gerealiseer word (Bultmann [1941] 1967:47-48).

\section{Slot}

Bly daar 'n mitologiese res oor nadat die NuweTestamentiese verkondiging ontmitologiseer is? Vir mense wat spreke oor God se beslissende eskatologiese handeling as mitologie beskou, moet daar vir seker 'n mitologiese res oorbly. Tog is dit nie meer mitologie in die ou sin van die woord, sodat dit nou oorbodig word met die verdwyning van die ou mitologiese wêreldbeeld nie. Die heilsgebeure is geen mirakelagtige, bo-natuurlike gebeure nie, maar 'n historiese gebeurtenis in ruimte en tyd. Deur dit só voor te stel word die mitologiese sluier weggeneem en kom die Nuwe-Testamentiese verkondiging tot sy reg, naamlik as aankondiging van die paradoks dat God se eskatologiese handeling voltrek in die lewe van 'n konkrete historiese persoon. Net so is die verkondiging ook nie die misterieuse woorde van 'n orakel nie, maar sober verkondiging van die persoon en lotgevalle van Jesus van Nasaret en die betekenis daarvan as heilsgebeure. Dit kan wel verstaan word as historiese fenomeen deur die geesteswetenskappe en kan selfs as moontlike wêreldbeeld beskou word. Die verkondiging self maak egter die aanspraak dat dit God se eskatologiese spreke is (Bultmann [1941] 1967:48).

Predikante, apostels en die kerk is sosio-historiese fenomene met 'n geskiedenis wat deel vorm van 'n kultuur. Tog is hulle eskatologiese fenomene (Bultmann [1941] 1967:48). Hierdie aanspraak is 'n struikelblok (skandalon) wat net oorkom kan word deur geloof. Hoewel al hierdie fenomene histories, sosiologies en sielkundig ondersoek kan word, bly hulle vir geloof eskatologiese fenomene. Dit is juis die feit dat dit nie bewys kan word nie, wat die Christelike geloof beveilig teen die aanklag dat dit mitologie is. Die transendensie van God word nie immanent gemaak soos in die mite nie. Nee, die paradoksale teenwoordigheid van God word bevestig daamee dat 'die Woord mens geword het' (Bultmann [1941] 1967:48).

\section{Kritiese waardering Die noodsaaklikheid van ontmitologisering}

Ontmitologiering is nie alleen 'n hermeneutiese metode nie, maar opdrag en verantwoordelikheid (o.a. Fuchs 1969:166167; Luz 1966:367; Pelser 1987:189; Schelkle 1985:265). Dit word begrond deur die verantwoordelikheid van'n predikant om die uitdaging wat die evangelie rig, só effektief aan sy gemeente oor te dra dat hulle die keuse vir geloof sal maak. Dit is geen eenvoudige taak nie, omdat die konsepte waarin die evangelie verwoord is, nie meer vir hedendaagse mense verstaanbaar is nie. Dit noodsaak ontmitologisering (Perrin [1969] 1970:70). Dit het die Nuwe Testament reeds self begin doen deurdat mitiese konsepte uit die Joodse apokalptiek en selfs die misteriegodsdienste toegepas word op die historiese persoon van Jesus van Nasaret (Dunn 1977:294).

\section{Gebrekkige definiëring van die mite}

Bultmann se beskouing van die mite was ontoereikend, maar dit is nie waar Bultmann sy bydrae wou lewer nie (Perrin [1969] 1970:73). Bultmann het die Religionsgeschichtliche definisie gebruik, soos Gogarten (Schmithals 1995:171-178).

Kritiek dat Bultmann drie definisies gebruik vir die mite: die mite as mitiese wêreldbeeld, die godsdiens-historiese definisie en laastens die mite as uitdrukking van menslike selfverstaan (Thiselton 1980:252-258), gaan nie op nie. Die mitiese wêreldbeeld is nie ' $n$ definisie nie, maar die mitiese verwysingsraamwerk as werklikheidsbeskouing waarbinne die mite verstaan word. Net so is die intensie van die mite nie gelyk aan 'n definisie nie, maar dui gewoon op dit waarna die mite verwys, naamlik menslike eksistensie.

Die definisie van mite was nie vir Bultmann die belangrikste aspek in sy hermeneutiese program is nie (vgl. Bultmann [1941] 1967:179) en fokus hierop het aandag weggelei van waaroor dit eintlik gaan naamlik die mitiese denkwyse: dat die werklikheid oop sou wees vir bonatuurlike ingrype. Dit kontrasteer met die geslote werklikheidsverstaan van die natuurwetenskap. Selfs al sou kwantumfisika die kousaliteitsbeginsel tot 'n geringe mate gerelativeer het, word die werklikheid geensins oopgemaak vir bonatuurlike ingrype nie en is die eksperimentele metode nie laat vaar nie (Bultmann [1941] 1967:179-181).

\section{Inkonsistente ontmitologisering}

Bultmann het self nie konsekwent ontmitologiseer nie. Die mitiese apokaliptiese verwagting van die koninkryk van God wat hy aan Jesus toeskryf, het hy nie ontmitologiseer nie, ten einde dit te koppel het aan die uitbly van die paroesie. Die Paasgeloof het hy ook nie ontmitologiseer nie 
(Fuchs 1964:119). Sy insig, naamlik dat die mite 'n bepaalde selfverstaan eerder as kosmologie verteenwoordig, het hy ook nie gemotiveer soos wat hy met die proses van ontmitologisering gedoen het nie (Dunn 1977:295).

\section{Eliminering van die mite}

Die liberale teologie het die mite uit die verkondiging weggesny. So wou Bultmann nie werk nie. Hy wou die mitiese spreke interpreteer eerder as elimineer. Sy aanvanklike inhoudelike kritiek (Sachkritik) van die Nuwe Testament het danksy die invloed van Jonas se ontmitologisering van die Gnostiese literatuur tot 'n ontmitologiseringsprogram gegroei. Tog het hy die mitiese geëlimineer deur die objektiewe en ontoereikende mitiese voorstellings met eksistensiale voorstellings te vervang (Robinson 1964:34-35).

\section{Objektiverende beskouing van (mitiese) taal}

Bultmann het taal, ook mitiese taal, as objektiverend hanteer. Die objektiverende spreekwyse van mitiese taal versluier die ware intensie om 'n bepaalde selfverstaan tot uitdrukking te bring. Ontmitologisering beweeg weg van taal na verstaan (selfverstaan) voor mitiese taal dit tot uitdrukking gebring het. Hierdie verstaan skyn vir Bultmann meer outentiek te wees as die taal waarin dit verwoord is (Robinson 1964:37-38). Bultmann se siening van taal skiet tekort, soos sy beskouing dat taal op die mens gerig word en Dasein op eksistensie, terwyl beide Dasein en menswees op taal gerig is. Taal is nie die opsomming van eksistensiële denke, soos Bultmann meen nie. Denke is die opsomming van taal. Anders as Bultmann wat meen dat die mens vanweë sonde nie oor geloof beskik nie, meen Fuchs dat die mens, voor daar sonde was, afhanklik was van die spreke van God. Bultmann se siening oor die historisiteit van die mens moet gekwalifiseer word as die taligheid van eksistensie. Hoewel Bultmann reeds die term heilsgeskiedenis vervang het met heilgebeure, is die verlossingsgebeure eerder spraak- of woordgebeure (Robinson 1964:54-57, na aanleiding van Fuchs en Ebeling).

Bultmann se gelykstelling van mitiese spreke en objektivering van God is ongeldig. Dit is te betwyfel dat die Nuwe Testament werklik so 'n simplistiese, naïewe en primitiewe verstaan van die wêreld en van God gehad het. Bultmann se wye definisie van mites het onnodig meegebring dat analogieë en simbole ontmitologiseer is. Maar Bultmann se idee oor die waarheid waarna die mities verwoorde verkondiging in die Nuwe Testament verwys, is weer te eng. Dit lei tot 'n reduksie van die spreke oor God se handelinge, naamlik tot die Christusgebeure. So ontvlug Bultmann die historiese via die kerygma. Ontmitologisering behoort ontkerygmatisering in te sluit (Dunn 1977:297-298).

\section{Eksistensiale interpretasie Heidegger se invloed}

Bultmann se navolgers het, soos hy, Heidegger se eksistensiefilosofie in hulle hermeneutiek aangewend. Dit lei tot verskilpunte omdat Bultmann gesteun het op die vroeëre werk van Heidegger, en sy navolgers op sy latere werk. So was Fuchs byvoorbeeld van mening dat Bultmann nie reg laat geskied het aan die begrip selfverstaan nie, juis omdat hy nie Heidegger se latere denke hieroor in aanmerking geneem het nie (Van Til 1974:8-9).

Bultmann het begrippe ontleen aan Heidegger se eksistensiefilosofie, maar dit telkens vir sy eie doeleindes aangepas en met die heelwat ouer filosofies-teologiese tradisie van die Marburgse Neo-Kantianisme verenig. Uit hierdie tradisie, eerder as die eksistensiefilosofie, groei Bultmann se teologie. Bultmann se weergawe van eksistensialisme is daarom eiesoortig, met wortels wat verder terug strek as sy samewerking met Heidegger in die twintigerjare van die vorige eeu (Johnson 1987:22). Om Bultmann daarvan te beskuldig dat hy sy hermeneutiese program uitverkoop het aan Heidegger se eksistensiefilosofie, is daarom ongegrond.

\section{Selfverstaan}

Vir Bultmann is selfverstaan deel van voorverstaan en ondergeskik aan die doelwit om die teks te interpreteer. Hierdie benadering is te beperk. Die skopus van hermeneutiek moet voorsiening maak dat die teks die lesers kan interpreteer, sodat hulle selfverstaan aangespreek word deur die selfverstaan wat die teks voorstel. Dan is dit nie meer God, Jesus, die wêreld of taal wat ontmitologiseer word nie, maar die mens, vasgevang in 'n verwronge verhouding met homself. Dit is ongeldig om die openbaring te onderwerp aan 'n statiese ruimte met slegs tyd wat in beweging is. Lesers moet ingetrek word deur die evangelie tot waar ruimte en tyd sin maak in terme van 'n beweging, in terme van 'n pad wat geloop word, as tyd vir ander en ruimte vir ons. Bultmann se ontmitologisering benodig 'n meer radikale eksistensiale interpretasie wat die teks opnuut op 'n nuwe pad in beweging bring. Sodoende is die leser se selfverstaan nie slegs voorverstaan nie, maar ook die doel van die hermeneutiese proses. Verstaan moet minder klem kry as taal, want die teks interpreteer homself deur wat die teks oor ons sê (Robinson 1964:53-54).

\section{Die historiese Jesus-navorsing}

Die belangrikste vraag wat uit Bultmann se benadering na vore tree, is na die historiese Jesus. Fuchs vra waarom die woorde en optrede van die historiese Jesus vir die evangeliste so belangrik was dat dit vertel moes word, as dit genoegsaam sou wees om Jesus as Here te bely? Die Formkritik se antwoord dat die evangelie daardeur verkondig is, is nie genoegsaam nie. Die vraag bly waarom die evangeliste hulle nie tot die kerugma van die gekruisigde en opgestane Here beperk het soos Paulus nie. As hulle dit gedoen het, sou dit nie vir hulle moontlik gewees het om die evangelies te skryf nie. Fuchs meen die evangeliste se bedoeling was om die historiese Jesus nader aan lesers te bring deur die kerugma met die historiese Jesus aan te vul. Bultmann se ontoereikende hantering van die historiese Jesus is vir hom 'n leemte wat aangevul moet word (Fuchs 1964:113-115). 
Waarom was die vraag na die historiese Jesus nie vir Bultmann van wesenlike belang nie? Formkritik het vroeg in die twintigste eeu aangedui dat Jesus se boodskap wat deur die Sinoptici weergegee word, grotendeels nie outentiek was nie, maar gevorm is deur die vroegste Christelike groepe in verskillende stadia van ontwikkeling. Die aanvanklike tradisie oor Jesus is dus ingebed in die vroegste verkondiging en tegelyk daardeur bedek. Gevolglik is die Paasgeloof die draer en vormgewing van die evangelie. Hierdie konklusie het radikale gevolge vir Bultmann se benadering tot die historiese Jesus gehad. Sedert sy 1921-publikasie Geschichte der Synoptische Tradition en sy 1926-boek Jesus het Bultmann gepoog om die vroegste laag van Christelike verkondiging na te speur. Die poging het nie geslaag nie, omdat Jesus se eie prediking, asook die refleksie daaroor in die kerugma reeds verweef geraak het. Hy kon geen duidelike skeidslyn tussen die twee lae trek nie (Bultmann 1958:12-13). Gevolglik beskou hy die Sinoptici as deel van die geskiedenis van dogma en godsdiens (Bultmann 1963:374). In sy latere werk oor die vroegste kerk binne kontemporêre konteks (1949) het Bultmann Jesus in sy beskrywing oor laat Jodedom geplaas (Bultmann 1956:59-79). Uiteindelik kulmineer Bultmann se siening in sy Theologie (1956), waar hy Jesus se boodskap as vooronderstelling, eerder as deel van die Nuwe-Testamentiese teologie beskryf (Bultmann [1958] 1980:1)

\section{Relevansie van Bultmann se ontmitologisering}

Bultmann is verskeie male beskryf as die grootste teoloog wat die twintigste eeu opgelewer het. Dit is jammer dat hy in Suid-Afrika so min erkenning gekry het en dat sy werk nie die aandag gekry het wat dit verdien nie (Pelser 1987:162163). Intendeel: Loubser (1996:49) gaan so ver as om te sê dat dit die tydverdryf van 'n groot aantal Suid-Afrikaanse teoloë was om op Bultmann se sogenaamde (my invoeging) tekortkominge te wys. Dit laat die Suid-Afrikaanse teologiese konteks des te armer. Ten spyte van al die kritiek het baie van Bultmann se insigte oor ontmitologisering in Bybelse teologie neerslag gevind. In al meer teologiese kringe, soms wel met bepaalde reserwe, word erken dat ons in die Skrif met mitiese spreke te doen het en dat dit noodsaaklik is om dit vir hedendaagse mense te interpreteer (Pelser 1987:188). Die konstante krisis van die kerk is om gelowiges met die evangelie voor eksistensiële beslissings te stel, sodat hulle nie geloof as besitting beskou nie (Fuchs 1969:91). Die taak van die hermeneutiek om te ontmitologiseer kan nie ontkom word nie en is noodsaaklik vir geloof. James Dunn stel dit so: 'The dialectic of demythologising is the language of living faith' (Dunn 1977:301).

\section{Erkenning Mededingende belange}

Die outeur verklaar hiermee dat hy geen finansiële of persoonlike verbintenis het met enige party wat hom nadelig of voordelig kon beïnvloed het in die skryf van hierdie artikel nie.

\section{Literatuurverwysings}

Bultmann, R.K., 1956, Primitive Christianity in its contemporary setting, transl. R.H. Fuller, Fortress, Philadelphia.

Bultmann, R.K., 1958, Jesus and the word, transl. L. Pettibone Smith \& E. Huntress Lantero, Scribner's, New York.

Bultmann, R.K., 1963, History of the synoptic tradition, transl. J. Marsh, Blackwell, Oxford.

Bultmann, R.K. [1941] 1967, 'Neues Testament und Mythologie: Das Problem der Entmythologisierung der neutestamentlichen Verkundigung', in H.W. Bartsch (Hrsg.), Kerygma und Mythos, I: Ein theologisches Gespräch, pp. 1548, Theologische Forschung 2, Herbert Reich EvangelischerVerlag, HamburgBergstedt.

Bultmann, R.K. [1958] 1980, Theologie des Neuen Testaments, 8. Auflage, Mohr, Tübingen.

Dunn, J.D.G., 1977, 'Demythologizing - The problem of myth in the New Testament', in I.H. Marshall (ed.), New Testament interpretation: Essays in principles and methods, pp. 285-307, Paternoster, Exeter.

Fuchs, E., 1964, 'The New Testament and the Hermeneutic Problem', in J.M. Robinson \& J.B. Cobb (eds.), The new hermeneutic, new frontiers in theology, vol. 2, Harper $\&$ Row, New York.

Fuchs, E., 1969, Hermeneutik, vol. 4, Auflage, Mohr, Tübingen.

Johnson, R.A.,1987, Rudolf Bultmann: Interpreting faith for the modern era, The making of modern theology series, vol. 2, Collins, San Francisco.

Loubser, J.A., 1996, 'Aspekte van Bultmann se Pauliniese teologie', Nederduitse Gereformeerde Teologiese Tydskrif 37(1), 49-60.

Luz, U.,1966, 'Entmythologisierung als Aufgabe der Christologie', Evangelische Theologie 26, 349-368. http://dx.doi.org/10.14315/evth-1966-0702

Malan, G.J., 2000, 'Bultmann se ontmitologiseringsprogram herwaardeer', Hervormde Teologiese Studies 56, 1107-1118.

Ogden, S.M., 1985, Rudolf Bultmann: New Testament \& mythology and other basic writings, SCM, London.

Pelser, G.M.M., 1987, 'Die ontmitologiseringsprogram van Rudolf Bultmann', Hervormde Teologiese Studies 43, 162-191.

Perrin, N.R., [1969] 1970, The promise of Bultmann, Fortress, Philadelphia.

Robinson, J.M., 1964, 'Hermeneutic since Barth', in J.M. Robinson \& J.B. Cobb (eds.), The new hermeneutic, new frontiers in theology, vol. 2, Harper \& Row, New York.

Schelkle, K.H., 1985, 'Entmythologisierung in existentialer Interpretation', Theologische Quartalschrift 165(4), 257-266.

Schmithals, W., 1995, Zum Problem der Entmythologisierung bei Rudolf Bultmann, Zeitschrift für Theologie und Kirche 92, 166-206.

Thiselton, A.C., 1980, The two horisons: New Testament hermeneutics and philosophical description, with special reference to Heidegger, Bultmann, Gadamer and Wittgenstein, Paternoster, Exeter.

Van Aarde, A.G., 2011, 'Rudolf Bultmann: Sy mees invloedryke bydrae in die 20ste eeu: "Urchristentum", "Jesus", "Johannes"-kommentaar?", HTS Teologiese Studies/Theological Studies 67(3), Art. \#1076, 7 pages. http://dx.doi.org/10.4102/ hts.v67i3.1076

Van Til, C., 1974, The new hermeneutic, Presbyterian and Reformed Publishing Company, Philadelphia. 